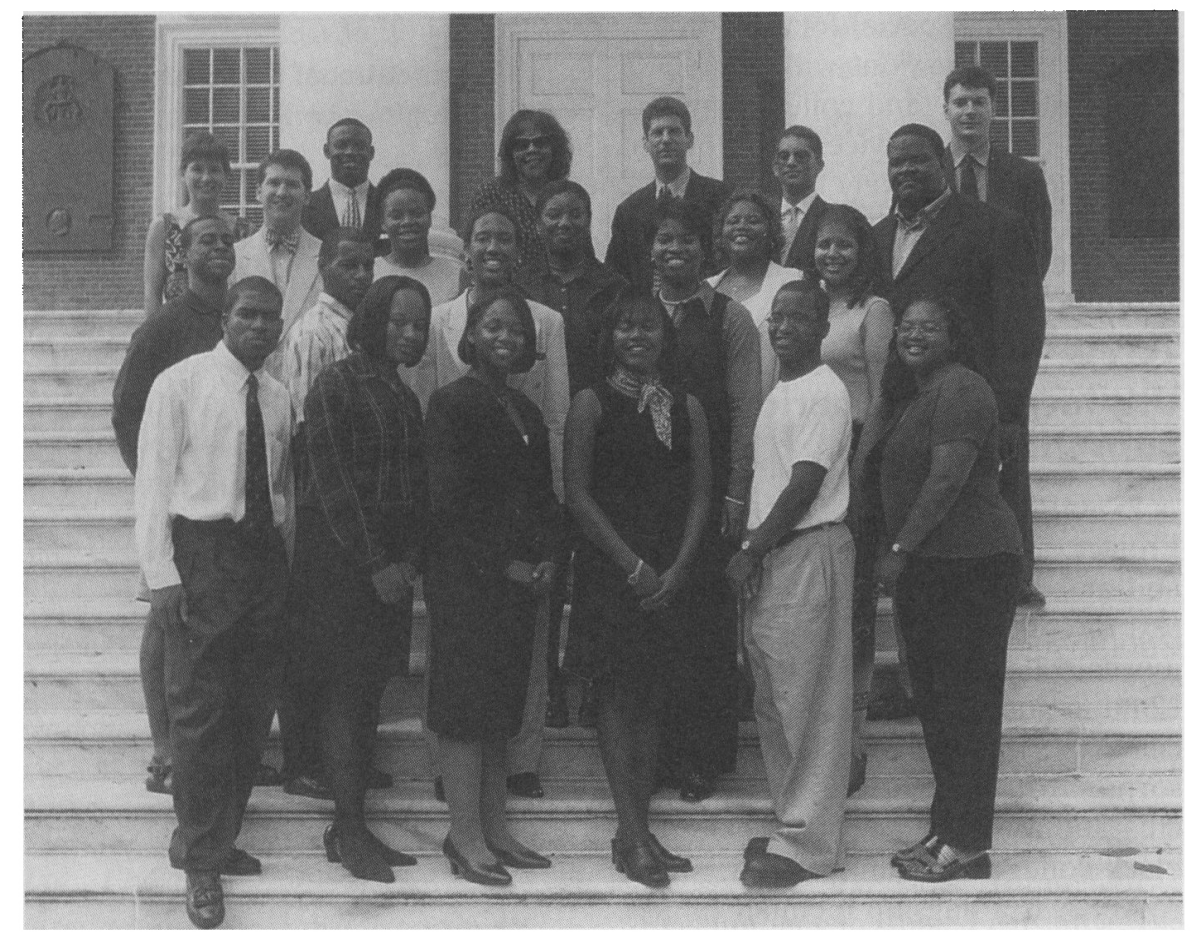

1998 Ralph Bunche Summer Institute participants and staff. Back Row (L-R): Stacy Nyikos (Graduate Assistant), Alan Kendrick (Graduate Assistant), Professor Paula D. McClain, Professor Steven Finkel (Director), Jeff Gulati (Graduate Assistant), Stan Humphries (Graduate Assistant. Third Row (L-R): Jay Shaylor (Assistant Director), Katrina Gamble, Elizabeth Green, Jabaria Willis, Marlow H. Colvin. Second Row (L-R): Ray Block, Arthdale Brown, Andra Gillespie, Kenyetta Alexander, Gloria Anglón. First Row (L-R): Melvin Rogers, Monique Lyle, Teah Williams, Doris Clark; James Gunn, and Aisha Raj.

African-American students to graduate school and to encourage their application to Ph.D. programs in political science. This year's class came from 15 schools as diverse as Smith College, Pepperdine University, and Central Arkansas State University.

While living on the grounds of UVA, the students spent five weeks in two graduate-level courses taught by distinguished members of the department's faculty and attended weekly lunches and dinners with visiting scholars from all over the U.S. The students toured Monticello, Thomas Jefferson's mountain home, and traveled to Washington, DC. Kaplan Testing Services administered a mock Graduate Record Examination and provided indepth analysis of their scores. And on June 26 , recruiters from 16 top graduate political science programs attempted to woo the students to their universities at a day-long recruitment fair.

Study at the Institute was intense but worthwhile. Monday through Thursday, the students met for four hours of either Professor Paula McClain's Race and American Politics course or a quantitative methods course, Political Analysis, taught by the Institute's director, Professor Steven Finkel. According to Ray Block, a Bunche Fellow from Howard University, the Institute was "the most worthwhile summer I have ever spent academically."

This year's program also proved one of the most successful in convincing students to apply to graduate programs in political science. According to Andra Gillespie, a fourthyear student at the University of Virginia, the collegiality of the program became a motivator for her to continue her study of political science. "At the end of one's college career," noted Gillespie, "one can begin to get lethargic about school. The Institute really challenged me to overcome that and got me excited about graduate school."

All of the students also reported marked improvement in their writing and research skills. "The Bunche Institute taught me how to think not only qualitatively and theoretically, but also how to back up my theories and qualitative observations with data and statistics," Jabaria Willis, a senior at Spring Hill College, said. Gloria Anglón of Providence College agreed. "The Institute has exposed me to areas of political science that I would not have seen in undergraduate school, plus I have met so many friends that will hopefully be fellow colleagues."

Because of its rigorous program, the Institute's scholars have seen great success. Yvette Alex-Assensoh. an assistant professor at Indiana University, Heather Dash, a graduate student at Emory University, anc Khalilah Brown, an entering graduate student at Ohio State are all Bunche alumnae. All three of them returned on June 26 to tell the students a little about how the Institute has impacted their lives. Many other alumni have attended and graduatec from top graduate and law program: over the past 12 years and three have been named assistant professors.

The Institute's namesake, Ralph Bunche, a 1934 Harvard University graduate, was the first African American to receive a doctorate in political science and the first to serv as the president of the American Political Science Association. In 1950 he also became the first African American to receive the Nobel Peace Prize.

The Institute has been held at the University of Virginia for the past three years. The program is supported financially by a grant from the National Science Foundation, the American Political Science Asso ciation, and by the University of Vir ginia.

\section{Spring Round of Minority Identification Project Big Success}

At the request of several core schools, a "Spring Round" has been added to the Minority ID Project. Many of the graduate schools have early-December application deadlines, and the Spring list better serves the needs of those schools. 
This spring, 56 promising minority students interested in pursuing graduate studies in political science were identified by political science departments at Amherst College, Butler University, University of California, Santa Cruz, Chicago State University, Goucher College, Harvard University, Marquette University, University of Michigan, Monmouth University, University of New Mexico, University of North Carolina, Ohio State University, University of Oklahoma, University of Rhode Island, Santa Clara University, University of South Carolina, Aiken, University of Southern California, Virginia State University, Washington University, and Xavier University. APSA would like to express its appreciation to these departments for their support and participation.

The Minority Identification project is a collaboration of undergraduate and graduate political science programs to attract talented minority undergraduate students to graduate study in the field and, ultimately, to increase diversity in the political science profession.

Faculty in university and college undergraduate programs talk with minority students about professional careers in political science and send the names of promising minority candidates for graduate study to the APSA. Participating graduate institutions actively recruit students identified by the Project, and make special

1998-99 APSA Minority Fellows Choose Grad Schools

All four 1998-99 Minority Fellows will be attending graduate school this fall. Latina Fellow Luz Iniz Gomez will enter the Ph.D. program in political science at Columbia. African-American Fellows Kimberly Clark and Temita Davis will attend the University of North Carolina and Clark University, respectively. Brandy Faulkner, an unfunded Fellow, has accepted admission to the University of North Carolina, Greensboro. efforts to provide financial aid to those admitted to their programs.

Currently, the Project circulates its list to 41 core schools and to several non-core schools. For more information about the Project, please contact minority_id@apsanet.org.

\section{Forty-Sixth Class of Congressional Fellows Named}

Continuing a five-decade tradition, APSA has named its 1998-99 class of Congressional Fellows. Chosen from a large and highly qualified group of political scientists, journalists, health professionals, and government employees, Fellows will spend a year in Washington learning how the legislative branch of the federal government works by joining the staffs of members of Congress and attending lectures and seminars.

The 1998-99 Congressional Fellowship Program class includes:

\section{Political Science Fellows}

David Auerswald, assistant professor, George Washington University

Thomas Brunell, visiting professor, University of California, Irvine

Colton Campbell, assistant professor, Florida International University

Lisa García Bedolla, Ph.D., Yale University

Eric Heberlig, Ph.D., Ohio State University

Benjamin Highton, Ph.D., University of California, Berkeley

David Leal, assistant professor, State University of New York, Buffalo (1998-99 Steiger Fellow)

\section{Journalism Fellows}

Natalia Feduschak, contributing editor, The Ukrainian Quarterly

Darcia Harris, staff writer, The $\mathrm{Wa}$ tertown Daily Times (1998-99 Congressional Quarterly Fellow)

APSA-MCI Communications Fellows

Daniel Lipinski, Ph.D., Duke University

Andrew Souvall, producer, KUTV, Salt Lake City, Utah
Carl Albert Fellows

Lesli McCollum, Ph.D., University of Oklahoma

German Fellows

Katherine Käufer, computer software translator, Graphitti Software, Cologne, Germany

Michael Kühlen, freelance journalist, Münster, Germany

\section{Federal Fellows}

Lora Becker, director of military intelligence staff, Defense Intelligence Agency

Donna Counterman, chief, EMS Requirements Staff, and EMS business manager, Central Intelligence Agency

Blane Dessy, executive director, $\mathrm{Na}$ tional Library of Education, U.S. Department of Education

Deirdre Foley, fair lending specialist, Federal Deposit Insurance Corporation

Christine Jackson, education program specialist, U.S. Department of Education

Patricia Jones, chief, Infrastructure Planning and Strategy, and senior computer scientist, National Security Agency

Arthur Menna, senior electronic engineer, National Security Agency

Carol Rest-Mincberg, senior management consultant, Department of Health and Human Services

Stacey Rosenberg, nuclear engineer, Nuclear Regulatory Commission

Foreign Affairs Fellows

William Adkins, team chief, Advanced Concepts Group, National Reconnaissance Office

Anne Alexander, Defense Intelligence Agency

Christopher Datta, country affairs officer (Israel, Jordan, Lebanon, Syria, West Bank), U.S. Information Agency

Delia Donatelli, deputy division chief, Satellite Systems Division, Department of the Air Force 